\title{
Gingival overgrowth following mechanical trauma during tooth preparation: a case report
}

\author{
Sulastrianah, ${ }^{*}$ Sri Oktawati
}

\section{Abstract}

Objective: To explain the management of gingival overgrowth caused by mechanical trauma during tooth preparation.

Methods: In this case report, a patient experience gingival overgrowth one day after trauma during tooth preparation for bridge. The patient feel severe paint especially when the inflamed gingiva is bitten during occlusion. In intraoral examination overgrowth is localized red to pink white, firm nodule gingiva. Management of the patient is surgical removal of the overgrowth gingiva.

Results: After one week of operation, the gingiva shows a good healing and no recurrency.

Conclusion: Gingival overgrowth may develop as a result from trauma or chronic irritation. The High speed rotary instrument may also make the trauma in the gingiva during tooth preparation. The carefully is needed when using this instrument.
Department of Periodontic, Faculty of Dentistry, Hasanuddin University, Makassar, Indonesia
${ }^{*}$ Corresponding to: Sulastrianah, Department of Periodontic, Faculty of Dentistry, Hasanuddin University, Makassar, Indonesia sulastrianahmuhtadi@gmail.com

Received: 10 June 2018 Revised: 18 June 2018 Accepted: 17 July 2018 Available online 1 August 2019

Keywords: Gingival abscess, Gingival overgrowth, Mechanical trauma, Reactive gingival lesion, Tooth preparation

Cite this Article: Sulastrianah, Oktawati S. 2019. Gingival overgrowth following mechanical trauma during tooth preparation: a case report. Journal of Dentomaxillofacial Science. 4(2): 114-116. D0I: 10.15562/jdmfs.v4i2.749

\section{Introduction}

Gingival overgrowth is characterized by an increase in the size of gingiva. ${ }^{1}$ This term has replaced gingival hyper plasia (increase in cell number) and gingival hypertrophy (increase in cell size) as these are histological diagnoses and do not accurately describe the varied pathological processes seen within the tissues. ${ }^{2}$ Based on the etiophatogenesis, this overgrowth could be low grade trauma, ${ }^{3}$ iatrogenic factors, drug-induced stimulus, underlying systemic disease, dental plaque, ${ }^{4}$ hormone related, ${ }^{5}$ vitamin $\mathrm{C}$ deficiency, ${ }^{6}$ hereditary, and idiophatic. ${ }^{7}$

Localized gingival overgrowth term as an epulis or a gingival reactive lesion. Itrefers to any solitary/ discrete, pedunculated or sessile swellings of the gingiva with no histologic characterization of a particular lesion. This reactive gingival lesion are painless with pedunculated or sessile base that vary in color, from light pink to red. ${ }^{8}$ Frequent diagnosis ofthis lesion is inflammatory rather than neoplastic and the classification may divided into Focal Fibrous Hyperplasia (FFH), Pyogenic Granuloma (PG), Peripheral Ossifying Fibroma (POF) and Peripheral Giant Cell Granuloma (PGCG). ${ }^{9}$ Otherwise, localised overgrowth of the gingivae may also be attributed to abscesses related to dental or gingival tissues. ${ }^{2}$

\section{Case Report}

A 23 years old male patient refers to Department of Periodontology Hasanuddin University Dental Hospital due to gingival overgrowth in distal region of tooth \#37 figure 1A. This overgrowth develops one day after trauma during tooth preparation for bridge. The patient feel severe paint especially when the inflamed gingiva is bitten during occlusion. Antibiotic and analgetic were prescribed for one week but the overgrowth still remain. In intraoral examination the distal part of \#37 corona is covered by localized red to pink white, firm nodule gingiva. The tooth has been partially prepared and was very sensitif even with ligth touch of cotton. No supuration upon gentle pressure. Radiographic examination revealed no pathologic condition in the bone figure $1 \mathrm{~B}$.

Management of the patient is surgical removal of the gingival lesion. Povidon iodine solution $1 \%$ is used to extraoral and intraoral disinfection. Septocaine is applied using an oral jet for local anesthesia. The crevicular incision using no. ${ }^{12}$ Blade is made in buccal, distal and lingual aspect of \#37 figure $2 \mathrm{~A}$ followed by excision of the overgrowth gingiva figure $2 \mathrm{~B}$. Horisontal incision in retromolar pad area also made to convenience the curretage of granulation tissue and scalling and root planing. figure $3 \mathrm{~A}$. The incision wound then closed by using simple interrupted technique suture figure 3B. Noneugenol periodontal pack is applied to prevent infection and minimize the pain during contack upon mastication. The patient is prescribed with analgetic and chlorhexidine mouthwash.

After one week of operation, the gingiva shows good healing and no recurrency of the overgrowth figure 4. 

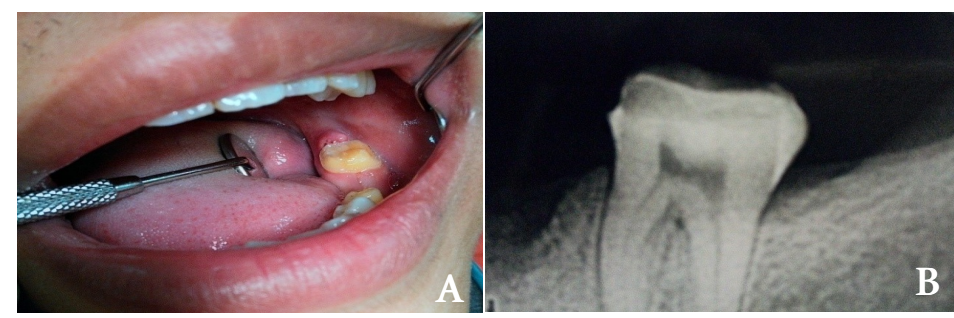

Figure 1 A. Gingival overgrowth in distal region of tooth \#37, B. Radiographic examination revealed no pathologic condition in the bone
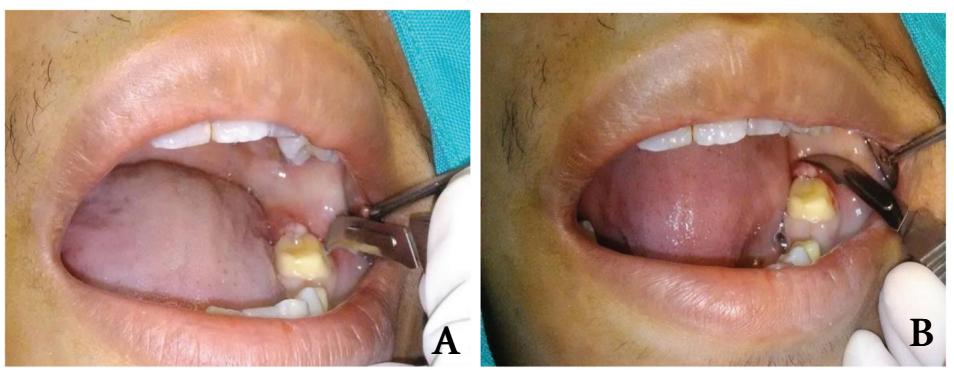

Figure 2 A. The crevicular incision using no. 12 blade is made in buccal, distal and lingual aspect of \#37, B. excision of the overgrowth gingiva

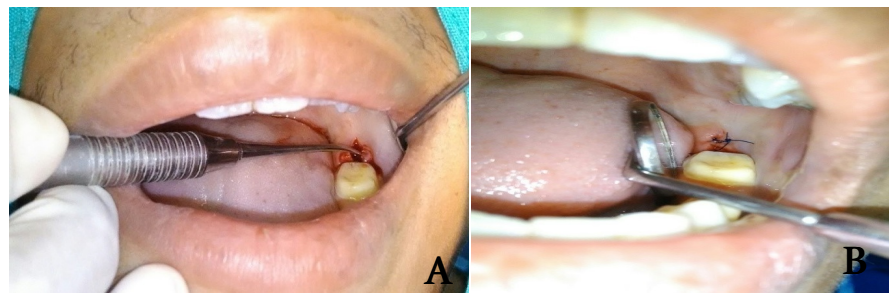

Figure 3 A. Horisontal incision in retromolar pad area, B. The incision wound closed by using simple interrupted technique suture
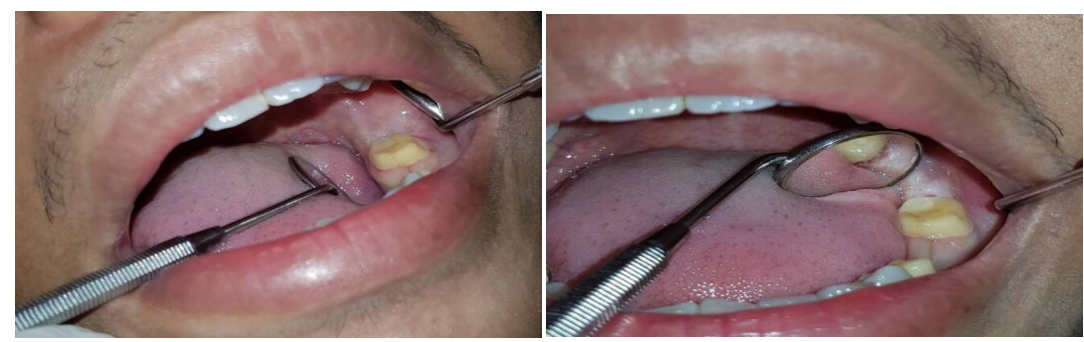

Figure 4 The gingiva shows good healing and no recurrency of the overgrowth

\section{Discussion}

Reactive gingival overgrowth are a common group of lesions that may be encountered during routine dental examinations. ${ }^{1}$ available records from the archives of the Department of Pathology, Dental School and the two main hospitals in Southeast of Iran Zahedan. It is caused by a range of lowgrade irritations to gingiva such as sharp edges of grossly carious teeth, dental plaque and calculus, illfitting dental/oral appliances, faulty dental restorations and food impactions. ${ }^{11}$ Most common localized reactive lesions of oral cavity are Focal Fibrous Hyperplasia (FFH), Pyogenic Granuloma (PG), Peripheral Giant Cell Granuloma (PGCG), Peripheral Ossifying Fibroma (POF). ${ }^{3}$

FFH is also known as irritational or traumatic fibroma. It is reactive as well as inflammatory lesion of connective tissue. It presents usually as a yellowish-white to pink colour with sessile base, smooth-surfaced, asymptomatic, soft nodule. The surface may be hyperkeratotic or ulcerated, owing to repeated trauma. ${ }^{12} \mathrm{PG}$ is a common reactive neoplastic lesion of the oral cavity, which is composed of granulation tissue and develops in response to local irritation or trauma. It is also known as pregnancy gingivitis. PGCG is a relatively common lesion of gingiva. It appears as a red or bluish-red mass. Lesion is generally intact, but it may be ulcerated..$^{13} \mathrm{POF}$ were exophytic, pedun-culated or sessile, nodular masses. Almost all POF were occur on the gingiva. Time of onset of lesions ranged from 1 to 36 months. Color ranged from pink to slightly red or bright red, and there may be ulceration on the surface. The lesion may asymptomatic or the patients may feel light discomfort and pain. Bleeding may also occur. Radiographic findings highlighted normal underlying bone structure. ${ }^{14}$ This lesion believed develop from gingival fibers or periodontal ligaments because it exclusively arise from gingiva, the subsequent proximity to the gingiva and periodontal ligament and the inverse correlation between age distribution of patients with POF. ${ }^{15}$ The infection of the patients gingiva in this case report begin approximately 24 hour after mechanical trauma during tooth preparation. The gingiva became overgrowth and the patient feels severe paint especially when the inflamed gingiva was bitten during occlusion. This condition is not suitable with reactive gingival overgrowth that results as a response to chronic low grade irritation. ${ }^{16}$ Therefore, the gingival abscess may be considered.

A gingival abscess is a localized painful swelling that affects only the marginal and interdental gingiva and is normally associated with subgingivally impacted foreign objects. ${ }^{17}$ These condition may have varying presentations but are often raised, fluctuant and erythematous as well as being tender to palpation. Pericoronitis around a partially erupted tooth may have a similar appearance. ${ }^{2}$

There is lack of publication about high speed rotary instrument trauma in the gingiva. In a report about high speed laseration in oral mucosa, the rotary instrument had lacerated 
the floor of the mouth and caused simultaneous avulsion and thrombosis of a sublingual vein. ${ }^{18}$ Other study about gingival injury associated with the abrasive erosion using air-abrasive technique, there is partial destruction of epithelium, damage of epithelium remnants, and exposure of connective tissue. ${ }^{19}$

Human gingiva have some devence mechanism. This is include anatomical factor (stipling), mucous barrier (saliva and gingival crevicular fluid), epithelial barrier and local inflammatory response. When the epithelial disrupt by mechanical trauma or by bacterial invasion, the final barrier local inflammatory responsemay activated. This respons prevent the penetration of bacteria to the connective tissue. A seriesof reactions brings about local changes like increased vascularization leading to increased fluid collection and cellular exudation that eventually causes accumulation of serum proteins and phagocytic cells in the affected area. ${ }^{20}$

The basic treatment of gingival overgrowth are by elimination of the aetiological factors and surgical removal of the lesion. ${ }^{21}$ Surgical scalpel is the classic techniques used for removing the hyperplastic lesion. ${ }^{22}$ Other technique using electrocauter. ${ }^{23}$ and diode lasers. ${ }^{24} \mathrm{~A}$ conventional surgical technique needs a high level of skill, accurate planning of incisions and repositioning of tissues to achieve normal anatomy of the tissue 21 with tissue removal as minimum as possible. ${ }^{25}$ Tissue biopsy and histopathological examination can be used to deliver a definitive diagnosis. This is usually considered after an initial phase of management if resolution of the gingival overgrowth is not fully achieved. ${ }^{2}$

\section{Conclusion}

Gingival overgrowth may develop as a result from trauma or chronic irritation. The High speed rotary instrument may also make the trauma in the gingiva during tooth preparation. The carefully is needed when using this instrument.

\section{Acknowledgment}

The authors would like to thank to Dr. drg. Mardiana A. Adam as a chairman of periodontology Departement dentistry Faculty of Hasanuddin ogy Departement dentistry Faculty of Hasanuddin University and drg. M.Ruslin, M.Kes, Sp. BM as a director of Hasanuddin university Dental Hospital for providing us with good environment and facilities to complete this project.

\section{Conflict of Interest}

The authors report no conflict of interest.

\section{References}

1. Agrawal AA. Gingival enlargements: differential diagnosis and review of literature. World J Clin Cases 2015;3: 779-789.

2. Beaumont J, Chesterman J, Kellett M, et al. Gingival overgrowth: part 1: aetiology and clinical diagnosis. $\mathrm{Br}$ Dent J 2017;222: 85-91.

3. Buchner A, Shnaiderman-Shapiro A, Vered M. Relative frequency of localized reactive hyperplastic lesions of the gingiva: a retrospective study of 1675 cases from Israel. J Oral Pathol Med 2010;39: 631-638.

4. Rossmann JA. Reactive lesions of the gingiva: diagnosis and treatment options. Open Pathol J 2011;5: 23-32.

5. Lai B, Muenzer J, Roberts MW. Idiopathic gingival hyperplasia: a case report with a 17-year followup. Case Rep Dent 2011;986237: 1-6

6. Omori K, Hanayama Y, Naruishi K, et al. Gingival overgrowth caused by vitamin $\mathrm{C}$ deficiency associated with metabolic syndrome and severe periodontal infection: a case report. Clin Case Reports 2014;2: 286-295.

7. Trackman PC, Kantarci A. Connective tissue metabolism and gingival overgrowth. Crit Rev Oral Biol Med 2004;15: 165-175

8. Gandhi B, Dhuvad, Jigar; et al. Reactive lesions of oral cavity. Natl J Integr Res Med 2016;7: 154-157.

9. Kadeh H, Saravani S, Tajik M. Reactive hyperplastic lesions of the oral cavity. Iran J Otorhinolaryngol 2015;27: 137-144

10. Hunasgi S, Koneru A, Vanishree M, et al. Assesmentof reactive ginival lesions of oralcavity: a histopatological study. J Oral Maxillofac Pathol 2017;21: 30-35.

11. de-Santana ST, Martins-Filho PRS, Piva MR, et al. Focal fibrous hyperplasia: a review of 193 cases. J Oral Maxillofac Pathol 2014;18: S86-89.

12. Gandhi B, Dhuvad JJABD. Reactive lesions of oral cavity. Natl J Integr Res Med 2016;7.

13. Mergoni G, Meleti M, Magnolo S, et al. Peripheral ossifying fibroma : a clinicopathologic study of 27 cases and review of the literature with emphasis on histomorphologic features. 2015;19: 17-21.

14. Bhasin $\mathrm{M}$, Bhasin V, Bhasin A. Case report peripheral ossifying fibroma. Reports Dent 2013;497234: 153-155.

15. Shukla P, Dahiya V, Kataria P, et al. Inflammatory hyperplasia: from diagnosis to treatment. 2014;18: 7-9.

16. Herera D, Alonso B, de-Arriba L, et al. Acute periodontal lesions. Periodontol 2000 2014;65: 149-177.

17. Dhanda J, Thomas M, Kheraj A. High speed laseration. Br Dent J 2008;204: 351 .

18. Kollar JA, Wentz FM, Orban B. The reaction of clinically normal gingiva to abrasive injury. J Periodontol 1955;262: 95-98.

19. Verma E, Jhawar A. Defense mechanisms of gingiva. J Orofac Res 2014;4: 111-114.

20. Chesterman J, Beaumont J, Kellett M, et al. Gingival overgrowth: part 2: management strategies. Nat Publ Gr 2017;222: 159-165.

21. Ballini A, Scattarella A, Crincoli V, et al. Surgical treatment of gingival overgrowth with 10 years of follow-up. Head Face Med 2010;6: 1-7.

22. Funde S, Baburaj MD, Pimpale SK. Comparison between laser, electrocautery and scalpel in the treatment of drug-induced gingival overgrowth: a case report. 2015;1: 27-30.

23. Campos L, Gallottini M, Pallos D, et al. High-power diode laser on management of drug-induced gingival overgrowth: report of two cases and long-term follow-up. J Cosmet Laser Ther 2018;0: 1-5.

24. Tjiptoningsih, Umi G. "Enlargement gingival treatment on teeth 11 and 21. J Dentomaxillofac Sci 2016;1: 377-384.

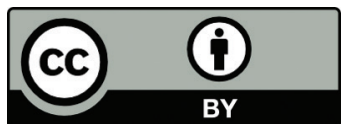

This work is licensed under a Creative Commons Attribution 